\title{
Fly ash from modern coal-fired power technologies: chloride ingress and carbonation of concrete
}

\section{Michael J. McCarthy}

Concrete Technology Unit, School of Science and Engineering,

University of Dundee, Dundee, Scotland, UK (corresponding author: m.j.mccarthy@dundee.ac.uk)

Hamza I. Yakub

Concrete Technology Unit, School of Science and Engineering,

University of Dundee, Dundee, Scotland, UK

\author{
Laszlo J. Csetenyi \\ Concrete Technology Unit, School of Science and Engineering, \\ University of Dundee, Dundee, Scotland, UK
}

Low-lime fly ashes produced from modern coal-fired power technologies (developed to enhance efficiency/lower emissions), including nitrogen oxide $\left(\mathrm{NO}_{x}\right)$ reduction, co-combustion, supercritical steam and oxy-fuel combustion, and their effects on chloride ingress and carbonation of concrete are investigated in this paper. Earlier work indicates that some of these technologies influence fly ash properties, but they mainly follow typical behaviour found for the material (consistence and compressive strength) in concrete. Both accelerated and normal-type exposure tests were carried out on a range of practical water/cement ratio concretes (also enabling interpolation for comparisons at equal $28 \mathrm{~d}$ strength). The test fly ash concretes were evaluated against (i) those containing three reference fly ashes covering a range of fineness and (ii) corresponding studies on fly ash concretes from the 1990s. The results show that there was an influence of fly ash fineness, reflected in reactivity/porosity (measured on mortar), and aspects of chemistry on chloride ingress, but there appeared to be minor material effects on carbonation. Comparison with the 1990s data indicated similar behaviour for the materials between studies for both properties. A relationship was also identified for the product of reactive alumina and sub-10 $\mu \mathrm{m}$ contents of the modern fly ashes and chloride resistance of concrete.

\section{Introduction}

Developments in electricity generation mean that some countries have seen a gradual change in how this is sourced (McCarthy et al., 2017a). For example, in the UK there have been reductions in the use of coal, with other forms of energy being more widely adopted (BEIS, 2017). At the same time, with coal-fired electricity production, there has been an increase in the implementation of technologies that enhance efficiency and/or reduce emissions (Beer, 2007; Buhre et al., 2005; Franco and Diaz, 2009). These include low-nitrogen-oxide $\left(\mathrm{NO}_{x}\right)$ methods (in- and post-combustion), co-combustion, supercritical steam and oxy-fuel combustion, a summary of which is given in Table 1. While they offer benefits to electricity generation, less is known about the fly ashes produced and their application in concrete. With the changing situation, including issues of availability (McCarthy et al., 2017a), modern coal-fired power technologies are likely to have a continuing impact on fly ash (Barnes, 2010).

In a previous study (McCarthy et al., 2018), the characteristics of fly ash from modern technologies and their influence on the fresh properties and strength of concrete were examined. For technologies involving changes to the fuel - for example, co-combustion - or the combustion process, such as $\mathrm{NO}_{x}$ reduction (in-combustion natural gas reburn system), the fly ashes were generally coarser and had a higher loss on ignition (LOI), while for other techniques, there was a less significant effect. The chemistry was affected in some cases (e.g. co- or oxy-fuel combustion), but mainly as expected given the coal used. The behaviour of fly ash was found to be in general agreement with earlier research (Dhir et al., 1998); for example, increased coarsening/LOI tended to give higher water requirement/reduced reactivity in mortar and concrete. Overall, the results indicate suitability of the materials in this application for the properties tested.

Fly ash is known to influence several aspects of durability, mainly corresponding to effects on the physical and chemical properties of concrete (CS, 2011; Sear, 2001). For example, in comparison to Portland cement (PC) concrete, reduced rates of chloride ingress may be achieved with fly ash due to enhanced microstructure and chemisorption/binding (Dyer, 2014; Liu et al., 2017). In contrast, increased carbonation rates can occur, reflecting differences in binder chemistry, although this appears to depend on the concrete mix composition and curing (Thomas, 2007) and exposure conditions (Bijen, 1996). Given their damaging effect on concrete structures, the influence of fly ash on these processes has received wide coverage (e.g. Angst et al., 2009; Atis, 2003; Baroghel-Bouny et al., 2009; Faustino et al., 2016; Loser et al., 2010; Marques et al., 2013).

Studies investigating the behaviour of different fly ashes on these durability properties have been limited. In the case of 
Table 1. Summary of modern coal-fired power technologies for enhanced efficiency/reduced emissions

\begin{tabular}{|c|c|}
\hline Development & Process/operation \\
\hline \multirow[t]{2}{*}{$\mathrm{NO}_{x}$ reduction } & $\begin{array}{l}\text { In-combustion: changes in conditions in the combustion chamber where } \mathrm{NO}_{x} \text { formation occurs (air/fuel supply and } \\
\text { temperature are normally regulated) }\end{array}$ \\
\hline & $\begin{array}{l}\text { Post-combustion: introduction of additives (e.g. ammonia or urea), with or without a catalyst (commonly a base metal } \\
\text { oxide) following combustion (e.g. SCR/SNCR) converting } \mathrm{NO}_{x} \text { to nitrogen }\left(\mathrm{N}_{2}\right)\end{array}$ \\
\hline Co-combustion & $\begin{array}{l}\text { Direct co-combustion involves firing of coal with various other materials (co-fuels), commonly renewable/waste } \\
\text { (e.g. wood-based, meat and bone meal, petroleum coke) }\end{array}$ \\
\hline Supercritical steam & $\begin{array}{l}\text { Combustion with supercritical steam cycles (increased pressure and temperature). Coal requirements are normally } \\
\text { reduced for these conditions }\end{array}$ \\
\hline Oxy-fuel combustion & $\begin{array}{l}\text { Oxygen replaces combustion chamber air. Emissions mainly comprise carbon dioxide, with capture normally required. } \\
\text { Part-recycling of flue gases is used to control oxygen levels/temperature }\end{array}$ \\
\hline
\end{tabular}

chloride ingress, some effect of fly ash fineness has been reported (Chindaprasirt et al., 2007), with aspects of the chemistry also identified as having a role (e.g. alumina; Dhir et al. (1991)), for equal strength concretes. Minor influences of different fly ashes in concretes of equal strength have been found for carbonation under both accelerated (Dhir et al., 1998) and normal-type (Thomas and Matthews, 1992) exposures, appearing to reflect a balance between physical and chemical factors. Given the effects noted for fly ash from modern coal-fired power technologies (McCarthy et al., 2018), it is possible that they may affect chloride ingress and carbonation of concrete, and a study was established to address this.

\section{Research programme}

In order to investigate modern coal-fired power technology influences, fly ashes were obtained from various sources (mainly from within the UK) providing reference and test materials. Following characterisation of their properties, concrete mixes were developed, covering the practical range of water/cement $(\mathrm{w} / \mathrm{c})$ ratios relevant to the durability properties being studied (BSI, 2015). This enabled comparisons at equal w/c ratio and interpolation to specific concrete strengths for evaluation on this basis. The tests for chloride ingress and carbonation of concrete followed both $(i)$ accelerated (electric field, high concentration) and (ii) normal-type exposures (i.e. corresponding to practical conditions).

As the collection of fly ash samples before and after introducing the modern coal-fired technologies was not possible, the test results were evaluated with respect to three reference fly ashes. Supporting experiments investigating the microstructure and reactivity of cement/fly ash mortars were carried out to assist with interpreting the durability results. Comparisons were also made with data from studies examining chloride ingress and carbonation of fly ash concretes from the early 1990s (Dhir et al., 1991; Thomas and Matthews, 1992).

\section{Materials}

A PC (CEM I) of strength class 52.5 N, as per BS EN 197-1 (BSI, 2011), was used in combination with the fly ashes for the various tests on mortar and concrete.
Table 2. Characteristics of reference fly ashes used during the study

\begin{tabular}{|c|c|c|c|}
\hline \multirow[b]{2}{*}{ Characteristic } & \multicolumn{3}{|c|}{ Fly ash } \\
\hline & FA1 & FA2 & FA3 \\
\hline \multicolumn{4}{|l|}{ Physical properties } \\
\hline LOI: \% & $4 \cdot 4$ & $4 \cdot 0$ & $5 \cdot 9$ \\
\hline Fineness (45 $\mu \mathrm{m}$ sieve): \% & $9 \cdot 6$ & $13 \cdot 2$ & $32 \cdot 8$ \\
\hline Water requirement: \% & 95 & 93 & 100 \\
\hline$D 50^{\mathrm{a}}: \mu \mathrm{m}$ & $12 \cdot 1$ & $14 \cdot 1$ & $28 \cdot 2$ \\
\hline \multicolumn{4}{|l|}{ Oxide composition: \% } \\
\hline Calcium oxide $(\mathrm{CaO})$ & $3 \cdot 01$ & $2 \cdot 31$ & 4.03 \\
\hline Silicon dioxide $\left(\mathrm{SiO}_{2}\right)$ & $48 \cdot 39$ & $49 \cdot 81$ & $43 \cdot 40$ \\
\hline Aluminium oxide $\left(\mathrm{Al}_{2} \mathrm{O}_{3}\right)$ & $20 \cdot 12$ & $22 \cdot 31$ & $23 \cdot 28$ \\
\hline Iron (III) oxide $\left(\mathrm{Fe}_{2} \mathrm{O}_{3}\right)$ & 8.35 & 7.94 & $11 \cdot 01$ \\
\hline Potassium oxide $\left(\mathrm{K}_{2} \mathrm{O}\right)$ & $2 \cdot 80$ & $3 \cdot 42$ & $2 \cdot 67$ \\
\hline Sodium oxide $\left(\mathrm{Na}_{2} \mathrm{O}\right)$ & $2 \cdot 01$ & $1 \cdot 33$ & $1 \cdot 71$ \\
\hline Sulfur trioxide $\left(\mathrm{SO}_{3}\right)$ & 0.97 & $0 \cdot 89$ & 1.40 \\
\hline \multicolumn{4}{|l|}{ Mineral composition: \% } \\
\hline Quartz & $9 \cdot 8$ & $11 \cdot 1$ & 8.6 \\
\hline Haematite & $2 \cdot 2$ & $2 \cdot 3$ & $3 \cdot 2$ \\
\hline Magnetite & $0 \cdot 1$ & 0.2 & $0 \cdot 1$ \\
\hline Mullite & $10 \cdot 4$ & $11 \cdot 0$ & $15 \cdot 6$ \\
\hline Glass/others $^{b}$ & $73 \cdot 2$ & $71 \cdot 5$ & $66 \cdot 5$ \\
\hline
\end{tabular}

${ }^{a} D 50$ indicates the diameter of the particle at which $50 \%$ of the sample's particles are smaller than that value

${ }^{\mathrm{b}}$ Not including LOI

The fly ashes, from the UK and other parts of Europe, were mainly from bituminous coal, but in two cases they were produced from anthracite coal. Many power stations use $\mathrm{NO}_{x}$-reducing methods and hence some of the fly ashes were from a combination of these and the specific techniques being investigated. The fly ash properties have been given in full previously (McCarthy et al., 2018) and hence only a summary is included in Tables 2 and 3. FA1, FA2 and FA3, with a range of fineness, were used as references and were $(i)$ obtained from a power station operating at full capacity, (ii) a category S fly ash and (iii) sampled from a power station during the 1990s, respectively.

Test fly ashes FA4, FA5 and FA6 were produced with specific $\mathrm{NO}_{x}$-reduction methods. FA4 and FA5 used post-combustion techniques (selective catalytic reduction (SCR) and selective 
Table 3. Characteristics of modern fly ashes used during the study

\begin{tabular}{|c|c|c|c|c|c|c|c|c|c|}
\hline \multirow[b]{2}{*}{ Characteristic } & \multicolumn{9}{|c|}{ Fly ash } \\
\hline & FA4 & FA5 & FA6 & FA7 & FA8 & FA9 & FA10 & FA11 & FA12 \\
\hline \multicolumn{10}{|l|}{ Physical properties } \\
\hline LOI: \% & $2 \cdot 6$ & $3 \cdot 4$ & $7 \cdot 3$ & $13 \cdot 7$ & $17 \cdot 3$ & $9 \cdot 8$ & $2 \cdot 4$ & 1.4 & $5 \cdot 4$ \\
\hline Fineness ( $45 \mu \mathrm{m}$ sieve): \% & $12 \cdot 1$ & $15 \cdot 1$ & $22 \cdot 5$ & $24 \cdot 4$ & $27 \cdot 2$ & $29 \cdot 4$ & $20 \cdot 0$ & $29 \cdot 6$ & $19 \cdot 1$ \\
\hline Water requirement: \% & 96 & 96 & 98 & 103 & 105 & 104 & 97 & 96 & 101 \\
\hline$D 50^{\mathrm{a}}: \mu \mathrm{m}$ & $14 \cdot 8$ & $19 \cdot 1$ & $24 \cdot 0$ & $29 \cdot 7$ & $33 \cdot 1$ & $34 \cdot 0$ & $31 \cdot 1$ & $30 \cdot 8$ & $30 \cdot 3$ \\
\hline \multicolumn{10}{|l|}{ Oxide composition: \% } \\
\hline $\mathrm{CaO}$ & 1.91 & $3 \cdot 74$ & 1.64 & $3 \cdot 55$ & $2 \cdot 94$ & 4.63 & $4 \cdot 47$ & $4 \cdot 19$ & $4 \cdot 20$ \\
\hline $\mathrm{SiO}_{2}$ & $51 \cdot 42$ & $47 \cdot 07$ & $45 \cdot 74$ & $42 \cdot 86$ & $41 \cdot 98$ & $39 \cdot 41$ & $43 \cdot 97$ & 44.43 & $47 \cdot 70$ \\
\hline $\mathrm{Al}_{2} \mathrm{O}_{3}$ & $17 \cdot 34$ & $19 \cdot 93$ & $16 \cdot 55$ & $20 \cdot 92$ & $20 \cdot 82$ & $21 \cdot 07$ & $16 \cdot 34$ & $16 \cdot 00$ & $20 \cdot 08$ \\
\hline $\mathrm{Fe}_{2} \mathrm{O}_{3}$ & 8.96 & $9 \cdot 13$ & $7 \cdot 72$ & $6 \cdot 71$ & $8 \cdot 15$ & $12 \cdot 99$ & $7 \cdot 89$ & $8 \cdot 49$ & $12 \cdot 49$ \\
\hline $\mathrm{K}_{2} \mathrm{O}$ & $2 \cdot 04$ & $3 \cdot 37$ & 1.73 & $1 \cdot 55$ & $2 \cdot 05$ & $2 \cdot 52$ & 1.79 & 1.90 & $2 \cdot 47$ \\
\hline $\mathrm{Na}_{2} \mathrm{O}$ & $1 \cdot 74$ & $1 \cdot 44$ & $1 \cdot 24$ & 0.84 & 0.75 & $1 \cdot 19$ & 1.69 & $2 \cdot 88$ & $1 \cdot 50$ \\
\hline $\mathrm{SO}_{3}$ & $1 \cdot 45$ & $1 \cdot 24$ & 1.08 & $0 \cdot 80$ & $1 \cdot 24$ & $2 \cdot 55$ & 0.74 & 0.91 & $3 \cdot 39$ \\
\hline \multicolumn{10}{|l|}{ Mineral composition: \% } \\
\hline Quartz & $20 \cdot 7$ & $11 \cdot 1$ & $19 \cdot 0$ & $3 \cdot 9$ & $4 \cdot 8$ & $7 \cdot 0$ & $5 \cdot 6$ & $10 \cdot 7$ & $12 \cdot 8$ \\
\hline Haematite & $2 \cdot 4$ & $2 \cdot 7$ & $1 \cdot 7$ & $1 \cdot 4$ & $1 \cdot 5$ & $2 \cdot 6$ & $2 \cdot 4$ & $3 \cdot 0$ & $4 \cdot 5$ \\
\hline Magnetite & $0 \cdot 1$ & 0.2 & $0 \cdot 1$ & $0 \cdot 1$ & $0 \cdot 2$ & 0.4 & 0.2 & 0.2 & $0 \cdot 1$ \\
\hline Mullite & $7 \cdot 6$ & $8 \cdot 8$ & $10 \cdot 6$ & $9 \cdot 5$ & $11 \cdot 8$ & 11.9 & $5 \cdot 6$ & $6 \cdot 2$ & $17 \cdot 9$ \\
\hline Glass/others $^{\mathrm{b}}$ & $66 \cdot 6$ & $73 \cdot 8$ & $61 \cdot 3$ & $71 \cdot 4$ & $64 \cdot 4$ & $68 \cdot 3$ & $83 \cdot 8$ & 78.5 & $59 \cdot 2$ \\
\hline
\end{tabular}

${ }^{a} D 50$ indicates the diameter of the particle at which $50 \%$ of the sample's particles are smaller than that value

${ }^{b}$ Not including LOI

non-catalytic reduction (SNCR)). FA6 was from an incombustion natural gas reburn system. FA7, FA8 and FA9 used co-combustion, combining coal with different co-fuels. FA7 and FA8 were produced at the same power station (anthracite coal), sampled in winter and summer, with wood chips as the co-fuel and ammonia injected to assist in collection at the precipitators. For FA9 (from bituminous coal), petroleum coke had been adopted. FA10 and FA11 were produced with supercritical steam technology, while FA12 was obtained using oxy-fuel combustion with a $1 \mathrm{MW}$ trial burner (FA10, FA 11 and FA12 were tested for chloride ingress only).

While most fly ashes met BS EN 450-1 requirements (BSI, 2012), some were outside the limits for certain properties. The LOIs of the reference fly ashes were between 4.0 and $5.9 \%$, while those of the modern fly ashes ranged from 1.4 to $17 \cdot 3 \%$, with FA7, FA8 and FA9 exceeding the BS EN 450-1 limit (BSI, 2012), which may reflect anthracite coal used for FA7 and FA8. Fineness (45 $\mu \mathrm{m}$ sieve retention) varied from $9 \cdot 6$ to $32 \cdot 8 \%$ and $12 \cdot 1$ and $29 \cdot 6 \%$, respectively. The calcium oxide $(\mathrm{CaO})$ content for all fly ashes was less than $5 \cdot 0 \%$, with the sum of the main oxides (silicon dioxide $\left(\mathrm{SiO}_{2}\right)$, aluminium oxide $\left(\mathrm{Al}_{2} \mathrm{O}_{3}\right)$ and iron (III) oxide $\left.\left(\mathrm{Fe}_{2} \mathrm{O}_{3}\right)\right)$ being greater than $70 \%$, except for FA10 and FA11, which were slightly below this (possibly reflecting co-combustion). Most fly ashes had alumina contents around $20 \%$, although FA4, FA6, FA10 and FA11 were lower. The alkali content $\left(\mathrm{Na}_{2} \mathrm{O}_{\text {eq }}\right)$ ranged from $3 \cdot 5$ to $3.9 \%$ for the reference fly ashes and 1.9 to $4 \cdot 1 \%$ for the modern fly ashes, while sulfate levels were between 0.9 and $1.4 \%$ and between 0.8 and
$3 \cdot 4 \%$, respectively, with FA9 and FA12 close to and exceeding the BS EN 450-1 limit (BSI, 2012). The main mineral components were, with a few exceptions (e.g. quartz content of FA4 and FA6), typical for the coal used. The glass/others content, not including LOI, ranged from $66 \cdot 5$ to $73 \cdot 2 \%$ for the reference fly ashes and $59 \cdot 2$ to $83 \cdot 8 \%$ for the modern fly ashes.

The aggregates for concrete were a gravel in two size fractions $(10 / 20$ and $4 / 10 \mathrm{~mm})$ and a medium grade sand $(0 / 4 \mathrm{~mm})$, as per BS EN 12620 (BSI, 2002). Their particle densities were 2610, 2600 and $2630 \mathrm{~kg} / \mathrm{m}^{3}$, with corresponding water absorptions (laboratory dry to saturated surface dry (SSD)) of 1·3, 1.4 and $0.8 \%$, respectively. A superplasticising (SP) admixture based on a modified polycarboxylate ether to BS EN 934-2 (BSI, 2009) was used to control the consistency of concrete at a fixed water content.

\section{Concrete mix proportions and preparation}

The concrete mixes used are given in Table 4. They provided a range of w/c ratios and enabled comparisons at equal strength by interpolation, using an approach followed previously (Kandasami et al., 2012). The concretes had a free-water content of $1651 / \mathrm{m}^{3}$, with $30 \%$ fly ash in the binder. The aggregates (given at SSD in Table 4) had fine/total content ratios of $0 \cdot 40$ to $0 \cdot 44$, based on Teychenné et al. (1997). The SP admixture was used as required (with doses from 0.3 to $0.9 \%$ by mass of the binder) to achieve a slump of 100 to $150 \mathrm{~mm}$. Concrete was produced in a horizontal pan mixer, as described in BS 1881-125 (BSI, 2013a). After sample preparation, curing 
Table 4. Mix proportions of concretes used during the study

\begin{tabular}{|c|c|c|c|c|c|c|c|c|c|c|}
\hline \multirow[b]{3}{*}{ Mix } & \multirow[b]{3}{*}{ w/c ratio } & \multicolumn{9}{|c|}{ Concrete mix proportions ${ }^{\mathrm{a}}: \mathrm{kg} / \mathrm{m}^{3}$} \\
\hline & & \multirow[b]{2}{*}{ Free water } & \multicolumn{3}{|c|}{ Cement/addition } & \multicolumn{4}{|c|}{ Aggregate $^{b}$} & \multirow[b]{2}{*}{ Total } \\
\hline & & & PC & Fly ash & Total & Sand & $4 / 10$ & $10 / 20$ & Total & \\
\hline 1 & 0.65 & 165 & 180 & 75 & 255 & 895 & 370 & 685 & 1950 & 2370 \\
\hline 2 & 0.55 & 165 & 210 & 90 & 300 & 845 & 375 & 695 & 1915 & 2380 \\
\hline 3 & 0.45 & 165 & 255 & 110 & 365 & 775 & 375 & 695 & 1845 & 2375 \\
\hline 4 & $0 \cdot 35$ & 165 & 330 & 140 & 470 & 700 & 365 & 680 & 1745 & 2380 \\
\hline
\end{tabular}

aSP used in quantities necessary to achieve 100-150 mm slump

${ }^{\mathrm{b}}$ Aggregate values correspond to the SSD condition

was carried out in water at $20^{\circ} \mathrm{C}$ for 7 or (mainly) $28 \mathrm{~d}$, as indicated below, prior to preconditioning and/or testing.

\section{Test methods}

\section{Chloride ingress}

Chloride migration was measured on selected concretes using the NT Build 492 test (Nordtest, 1999). Cylinders of $100 \mathrm{~mm}$ dia. and $300 \mathrm{~mm}$ length were cast and water-cured for $28 \mathrm{~d}$, and then three $50 \mathrm{~mm}$ slices were cut from the cylinders, while avoiding the top $20 \mathrm{~mm}$. The sliced samples were pre-conditioned for $24 \mathrm{~h}$ by following the vacuum treatment procedure, using calcium hydroxide $\left(\mathrm{Ca}(\mathrm{OH})_{2}\right)$ solution. Next, the samples were put in rubber sleeves with $300 \mathrm{ml}$ of $0.3 \mathrm{M}$ sodium hydroxide $(\mathrm{NaOH})$ solution (anolyte) on the top surface and placed on supports in 121 of $10 \%$ sodium chloride $(\mathrm{NaCl})$ solution (catholyte) and the anode immersed in the anolyte. The electrodes were connected to a power supply, the anolyte temperature was measured and the voltage was adjusted according to the current. At the end of the test, the anolyte current and temperature were measured, and specimens split and sprayed with $0 \cdot 1 \mathrm{M}$ silver nitrate $\left(\mathrm{AgNO}_{3}\right)$ solution. The silver chloride $(\mathrm{AgCl})$ precipitation depth was recorded at seven locations and a non-steady state migration coefficient was determined using the NT Build 492 equation (Nordtest, 1999).

Chloride ingress was also determined using the prEN 12390-11 profiling method (CEN, 2013), with two $100 \mathrm{~mm}$ cubes. Following $28 \mathrm{~d}$ water curing, each was cut into two specimens (initial and profile), which were used to measure chloride contents before (initial, $C_{\mathrm{i}}$ ) and after exposure (profile). The profile specimens were vacuum saturated with distilled water and all sides, except the cut face, sealed with wax. These were immersed in a $3.0 \% \mathrm{NaCl}$ solution at $20^{\circ} \mathrm{C}$ for $90 \mathrm{~d}$. The initial chloride content was determined by grinding $1-5 \mathrm{~g}$ of powder from this (initial) specimen and digesting it using $5 \mathrm{~mol} / \mathrm{l}$ nitric acid. The solution was filtered and chloride content (by mass of specimen) determined by potentiometric titration, as described in BS EN 14629 (BSI, 2007).

Chloride contents of profile specimens were determined by grinding layers (a minimum of eight, at set depths) from the exposed concrete surface. The depths were based on prEN 12390-11 (CEN, 2013), depending on the cement/combination and w/c ratio of concrete. Chloride contents were also measured by acid digestion, filtration and potentiometric titration. The non-steady state chloride diffusion coefficient/surface chloride were evaluated by non-linear regression curve fitting to the data and Fick's second law of diffusion, as described in prEN 12390-11 (CEN, 2013). This ignored the surface layer and included values to a depth of $C_{\mathrm{i}}+0.015 \%\left(C_{\mathrm{i}}\right.$ ranged from 0.034 to $0.045 \%$ during the tests), with correlation coefficients for all data $>0.95$.

\section{Carbonation}

Accelerated carbonation tests were based on BS 1881-210 (BSI, $2013 \mathrm{~b})$, but used a lower carbon dioxide $\left(\mathrm{CO}_{2}\right)$ concentration $(2 \cdot 0 \%)$ and a longer test period (20 weeks) than given in the standard, with samples FA1-FA9 examined. Following $28 \mathrm{~d}$ of water curing, the two $100 \times 100 \times 400 \mathrm{~mm}$ prisms were dried for $14 \mathrm{~d}$ at a temperature of $20^{\circ} \mathrm{C}$ and $55 \%$ relative humidity (RH). The prisms were sealed on all but two faces and were introduced to the exposure tank at the above carbon dioxide concentration, a temperature of $20^{\circ} \mathrm{C}$ and $55 \% \mathrm{RH}$. Periodically $(2,4,6,10$, 15 and 20 weeks), $50 \mathrm{~mm}$ slices were split from the prism specimen, which was then resealed and returned to the exposure. The slice was cleaned and sprayed with phenolphthalein $\mathrm{pH}$ indicator, with the colour change measured at five points on the edge of each slice after $24 \mathrm{~h}$. The carbonation depth was taken as the mean of 20 readings (10 per prism).

The normal-type exposure test conditions followed those given in prEN 12390-10 (CEN, 2007) - that is $0.035 \%$ carbon dioxide, $20^{\circ} \mathrm{C}$ temperature and $65 \% \mathrm{RH}$ - using two $100 \times 100 \times 400 \mathrm{~mm}$ concrete prisms water-cured for $7 \mathrm{~d}$. At set times (140, 365 and $540 \mathrm{~d}), 50 \mathrm{~mm}$ slices were again split from the prism specimens. A similar procedure to that described above was used to measure carbonation depth. In this case, the mean of 40 measurements (four faces; 20 per prism) was taken as the depth.

\section{Results and discussion}

\section{Chloride ingress}

Initially, accelerated chloride tests were carried out to identify general behaviour of selected fly ashes. These included three fly 


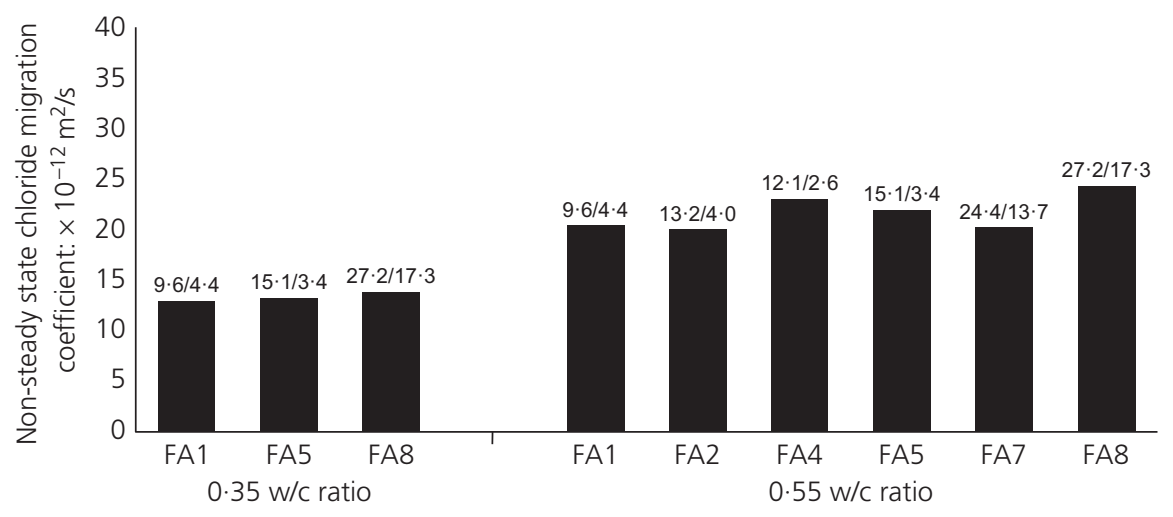

Figure 1. Comparison of chloride migration at different w/c ratios for selected fly ash concretes. Fineness (\% retained on $45 \mu \mathrm{m}$ sieve) and LOI (\%) values are shown above columns, respectively

ashes at $0.35 \mathrm{w} / \mathrm{c}$ ratio and six at $0.55 \mathrm{w} / \mathrm{c}$ ratio, namely FA1, FA2, FA4, FA5, FA7 and FA8 (reference, low $\mathrm{NO}_{x}$ (postcombustion) and co-combustion fly ashes), providing a range of properties. The results from these are given in Figure 1, with fineness and LOI of the fly ashes also shown.

As expected, chloride migration coefficients reduced with w/c ratio of concrete. In addition, the lowest value at $0.35 \mathrm{w} / \mathrm{c}$ ratio was obtained by FA1 (reference) concrete, while FA8 (co-combustion) had the highest value. At $0.55 \mathrm{w} / \mathrm{c}$ ratio, FA2 (reference) concrete had the lowest chloride migration coefficient, with those of the post-combustion low- $\mathrm{NO}_{x}$ fly ashes slightly higher - in particular FA4, which had a lower alumina content (albeit the test period is short), known to affect chloride binding (Dhir et al., 1991; Thomas et al., 2012) - with FA8 (co-combustion) again having the greatest value. The results, therefore, indicate some influence of fly ash properties on chloride ingress, with more noticeable effects at increased w/c ratio.

An example of the chloride profiles from the prEN 12390-11 (CEN, 2013) $90 \mathrm{~d}$ immersion tests for the 12 fly ash samples, in $0.45 \mathrm{w} / \mathrm{c}$ ratio concrete, is given in Figure 2. As indicated, these follow the expected behaviour for this type of chloride exposure test, giving a gradual reduction in chloride content with depth. Chloride levels at the concrete surface generally indicate a wider range between materials, of between 0.4 to $0.6 \%$ by mass of sample, which reduced, with less difference, to around $0.05 \%$ at $20 \mathrm{~mm}$ depth. The mean coefficient of variation for non-steady state diffusion with the three w/c ratios tested $(0.55,0.45$ and 0.35 using 9,12 and 7 fly ashes, respectively) was $16 \cdot 7 \%$, which compares favourably with values referred to for the test method (CEN, 2013).

The non-steady state diffusion coefficients for the various w/c ratio concretes are given in Figure 3. As with the NT Build tests, w/c ratio effects are apparent in the data, with greater reductions in diffusion coefficients mainly found between w/c ratios 0.55 and 0.45 than between 0.45 and 0.35 . For the different fly ashes, there were variations between concretes, although these tended to reduce with w/c ratio. For the reference fly ashes, similar results were obtained for FA1 and FA2 concretes, but higher values with the coarser FA3.

In the case of low- $\mathrm{NO}_{x}$ fly ashes, FA4 and FA5, which were relatively fine and had low LOI, and used post-combustion techniques, slightly higher chloride diffusion results were generally obtained in concrete compared to those with FA1 and FA2. Results for FA6 (in-combustion natural gas reburn system) concrete indicate increased values compared to FA4 and FA5. FA6 was coarser and had a lower alumina content than the other fly ashes, which may account for the effect.

The co-combustion fly ashes gave greater chloride diffusion values for wood chip materials, FA7 and FA8, which were coarser and had high LOI compared to the reference (FA1 and FA2) concretes with similar results to that of the relatively coarse FA3. For petroleum coke fly ash (FA9), lower chloride diffusion coefficients were obtained than for FA7 and FA8 concretes, but similar/higher values than for FA1 and FA2. This is despite a relatively high sulfate level, which may affect chloride binding (Frias et al., 2013; Yuan et al., 2009). Previous work has found no consistent effect (Dhir et al., 2005) and little change (Scott and Thomas, 2007) with accelerated chloride tests for various co-combustion fly ash concretes.

The supercritical and oxy-fuel fly ash concretes gave similar values (at the higher end of the range measured) during the tests. In the case of FA10 and FA11, these may correspond to lower alumina contents and relative coarseness of the materials. For FA12, the high sulfate content may reduce chloride binding, with the material also having moderate fineness.

\section{Carbonation}

The carbonation depths for the accelerated tests $(2 \cdot 0 \%$ carbon dioxide, $20^{\circ} \mathrm{C}$ temperature and $55 \%$ RH) on concretes 

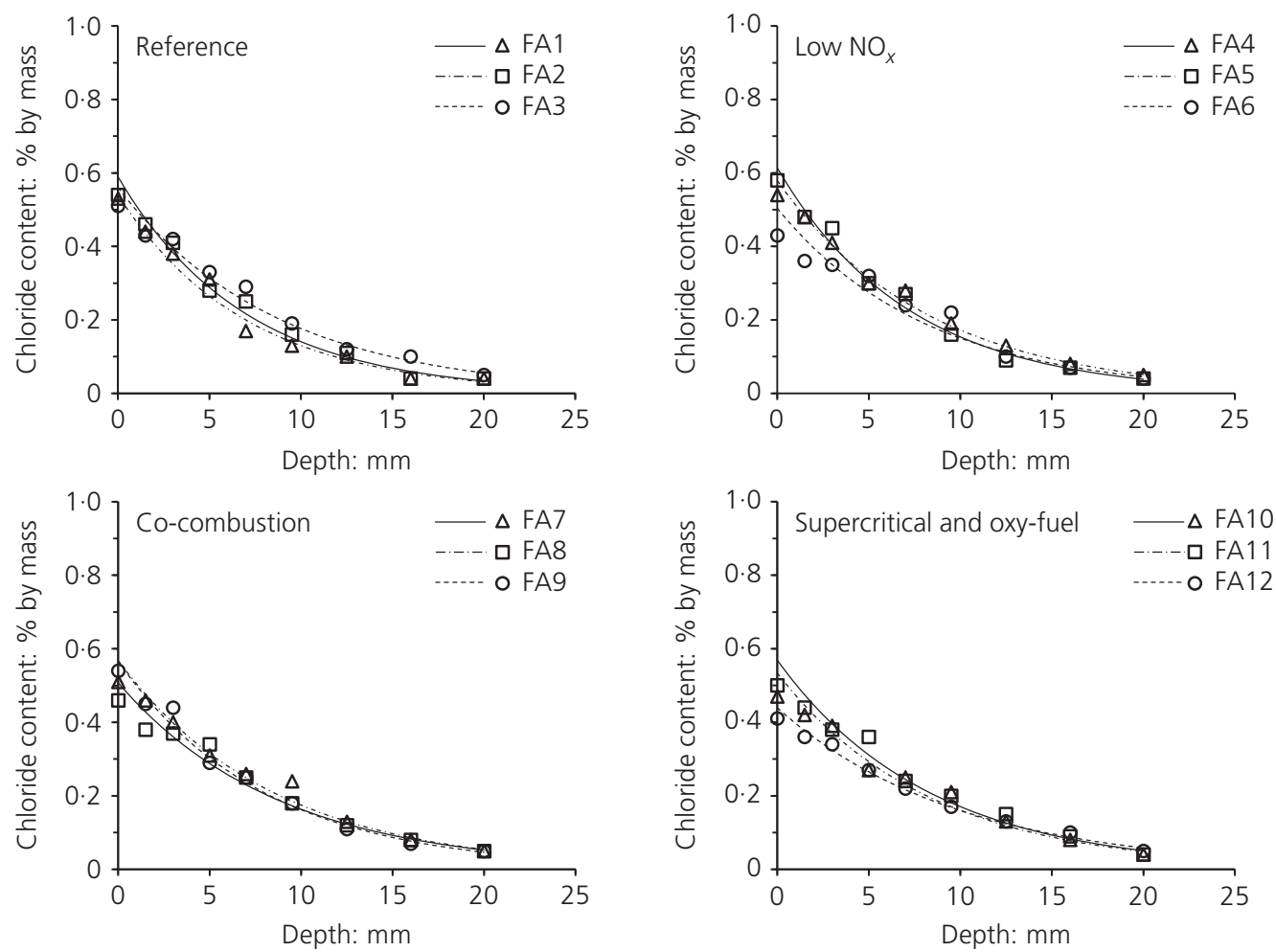

Figure 2. Variation of chloride content with depth for fly ash concretes at $0.45 \mathrm{w} / \mathrm{c}$ ratio

containing FA1-FA9 for the two w/c ratios against time are shown in Figure 4. These follow typical behaviour for carbonation, with increases in depth noted with exposure time, but at a reducing rate. Between the two w/c ratios, 0.55 and 0.45 , reductions of about 30 to $50 \%$ in carbonation depth were found for the concretes by the end of the test period. The results indicate little difference in the progress of carbonation between the reference fly ash concretes (FA1, FA2 and FA3), with all values within $1 \mathrm{~mm}$ during and by the end of the test at both w/c ratios.

The results for the $\mathrm{NO}_{x}$-reduction fly ash concretes, FA4 to FA6, and both w/c ratios, also gave minor variations between materials, irrespective of whether they were from post- or incombustion technologies, and the range was less than $1 \mathrm{~mm}$ over the test period. Comparisons with the reference fly ash concretes indicate little or no difference in carbonation depths.

The co-combustion fly ashes (FA7, FA8 and FA9) gave greater variations than those for the other concretes, with the petroleum coke fly ash (FA9) concrete being highest of those in this group (by up to $1.3 \mathrm{~mm}$ ) over the exposure period and for both w/c ratios. Differences in carbonation depth of less than $1 \mathrm{~mm}$ were mainly noted between the co-combustion and reference fly ash concretes. Previous accelerated tests (Dhir et al., 2005) gave some variations between fly ash concretes, including several using co-combustion, but no identifiable effect for this type of material.
Carbonation results for the fly ash concretes using the normaltype conditions $\left(0.035 \%\right.$ carbon dioxide, $20^{\circ} \mathrm{C}$ temperature and $65 \% \mathrm{RH}$ ) are shown in Table 5. As indicated, these were similar to the accelerated data, with increases in carbonation depth with time, but at a reducing rate. Again, there was little difference between the reference concretes, which were within $0.5 \mathrm{~mm}$ over the range of w/c ratios by $540 \mathrm{~d}$. Similarly, the $\mathrm{NO}_{x}$-reduction and co-combustion concretes had carbonation depths within $0.6 \mathrm{~mm}$ and $0.7 \mathrm{~mm}$ for the various w/c ratios by this test time. Overall, there were only small differences between the test and reference fly ash concretes.

A comparison is made between accelerated and normal-type carbonation exposure results in Figure 5. These indicate a cluster of data points for each of the two w/c ratios, with the accelerated exposure concretes giving slightly higher results (corresponding to differences in concentration and exposure periods). The results for both w/c ratios give similar behaviour between the accelerated and normal-type conditions, whilst differences in carbonation depths for the various fly ash concretes were within the range of repeatability measurements noted previously for these tests (Jones et al., 2000).

\section{Modern fly ash effects on chloride ingress and carbonation}

As mentioned above, the influence of fly ash on concrete durability mainly corresponds to its effect on the microstructure 

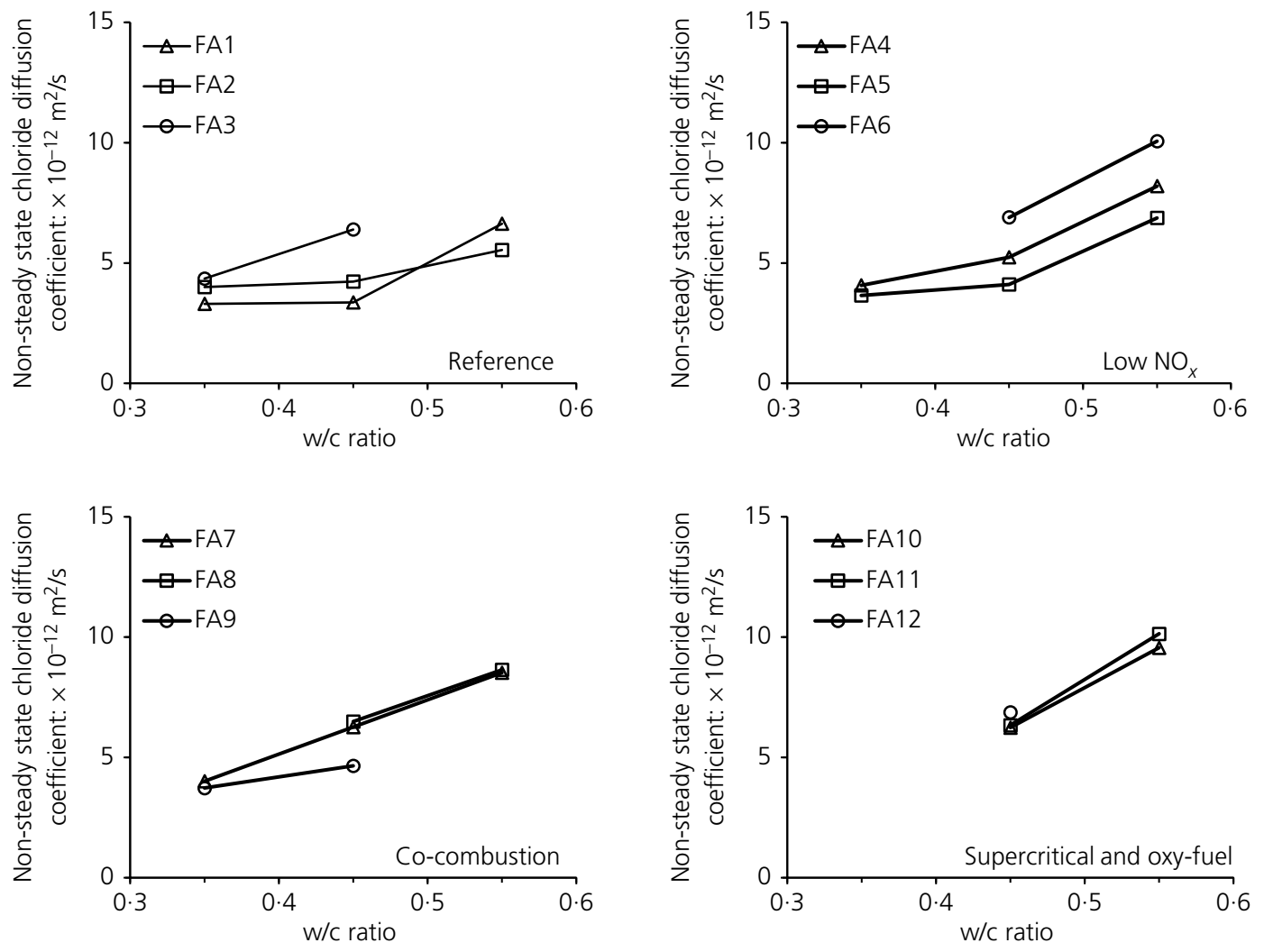

Figure 3. Non-steady state chloride diffusion coefficients for fly ash concretes at various w/c ratios

and aspects of the chemistry. In order to explore this and assist with the interpretation of the modern coal-fired power technology fly ash data, reactivity and porosity tests were carried out on fly ash mortars, and comparisons were made with fly ash data from corresponding tests on concretes carried out during the 1990 s, to establish whether the same type of effects were obtained.

Activity index tests followed the method described in BS EN 450-1 (BSI, 2012) - that is, comparing PC/fly ash and PC standard mortar (containing CEN-standard sand as per BS EN 196-1 (BSI, 2016), at 25\% fly ash in the binder and 0.5 w/c ratio) strengths at 28 and $90 \mathrm{~d}$ to provide a measure of reactivity. Tests using mercury $(\mathrm{Hg})$ intrusion porosimetry (MIP) to determine porosity were also made on standard mortars, with specimens $(8 \mathrm{~mm}$ dia. and approximately $20 \mathrm{~mm}$ length) taken from a larger-sized sample. These were introduced to acetone for $24 \mathrm{~h}$ to displace water, thus stopping hydration, and were oven dried for $24 \mathrm{~h}$. Mercury intruded the samples at variable pressure rates up to $230 \mathrm{~N} / \mathrm{mm}^{2}$, with pores above $0.0065 \mu \mathrm{m}$ being measured.

The results from the activity index tests at 28 and $90 \mathrm{~d}$ (McCarthy et al., 2018) are shown against fly ash fineness in Figure 6. These gave slight reductions with coarsening of fly ash, with the same effects at both 28 and $90 \mathrm{~d}$, and are similar to data obtained previously (Dhir et al., 1998). The results from selective fly ash mortar porosity tests at 28 and (mainly) $90 \mathrm{~d}$ are shown in Figure 6. These illustrate that slight reductions in porosity occurred between the two test ages, ranging from $<1 \mathrm{ml} / \mathrm{g}$ to around $3.5 \mathrm{ml} / \mathrm{g}$. Minor increases in porosity were noted with sieve retention - that is, coarsening of fly ash - at both test ages. The results indicate that reactivity and packing effects associated with finer material (Chindaprasirt et al., 2005) occur with the modern fly ashes.

To examine the effects of fly ash properties on chloride resistance, a comparison was made between the characteristics identified as influencing the process - alumina content, glass content and fineness (Chindaprasirt et al., 2007; Dhir et al., 1991; Papadakis, 2000; Thomas et al., 2012) - for the data from the current and an earlier study on fly ash concrete (Dhir et al., 1991). The basis for this is equal strength (cube) in both cases, which is likely to reduce the influence of microstructure on the process. There were differences in concrete mixes and materials (other than fly ash), but the intention was to establish if similar behaviour between studies occurred.

Figure 7 shows the relationships between chloride diffusion and the reactive alumina content in the fly ash - that is, that found in the alumino-silicate glass (Papadakis, 1999), 

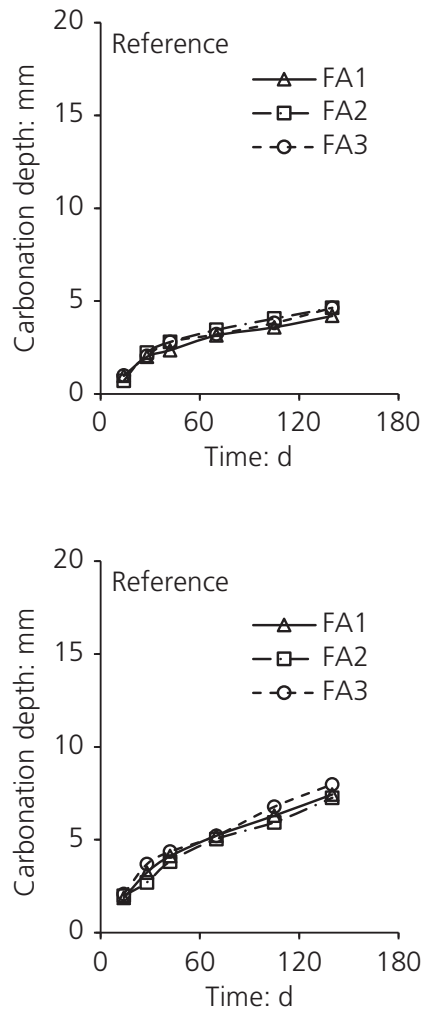

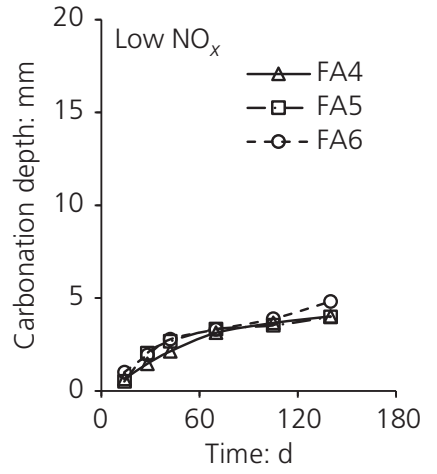

(a)
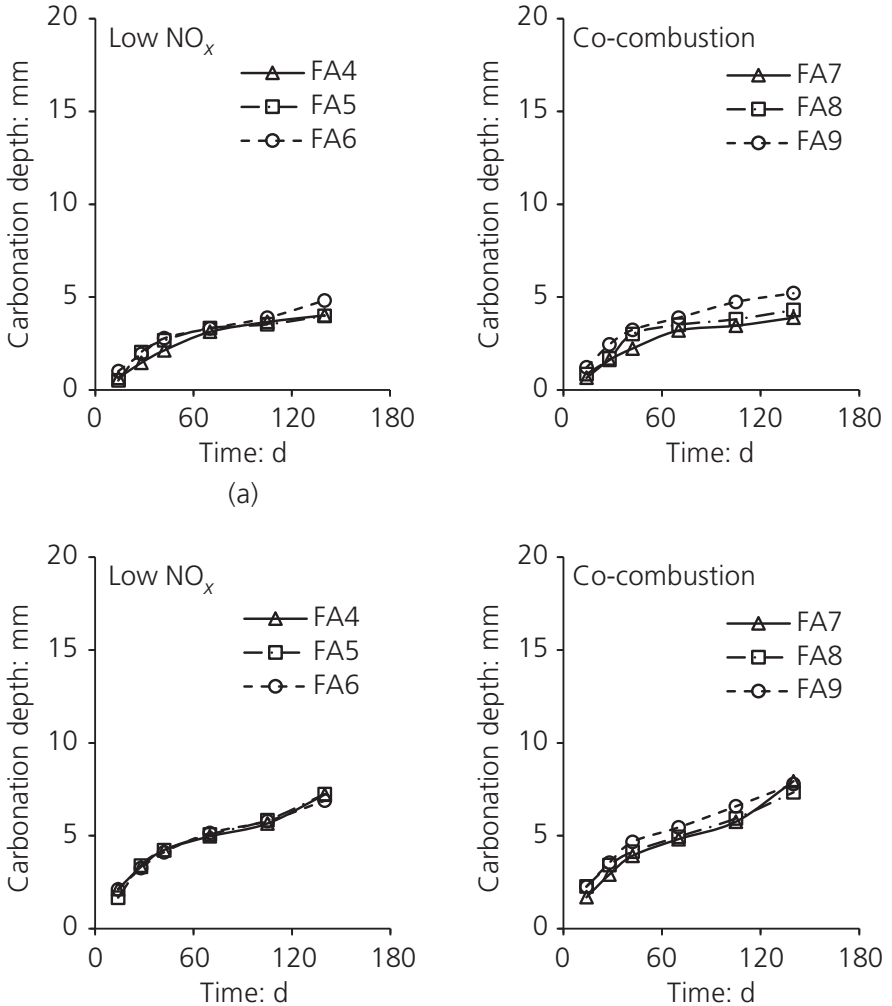

(b)

Figure 4. Accelerated carbonation rates of fly ash concretes at (a) $0.45 \mathrm{w} / \mathrm{c}$ ratio and (b) $0.55 \mathrm{w} / \mathrm{c}$ ratio

Table 5. Depth of carbonation for fly ash concretes under normal-type exposure conditions, mm

\begin{tabular}{|c|c|c|c|c|c|c|c|c|c|}
\hline \multirow[b]{3}{*}{ Fly ash } & \multicolumn{9}{|c|}{ Exposure period: $\mathbf{d}$} \\
\hline & \multicolumn{3}{|c|}{ w/c ratio 0.45} & \multicolumn{3}{|c|}{ w/c ratio 0.55} & \multicolumn{3}{|c|}{ w/c ratio 0.65} \\
\hline & 140 & 365 & 540 & 140 & 365 & 540 & 140 & 365 & 540 \\
\hline FA1 & $1 \cdot 5$ & $2 \cdot 8$ & $3 \cdot 4$ & $2 \cdot 6$ & $4 \cdot 7$ & $5 \cdot 9$ & $4 \cdot 7$ & $8 \cdot 0$ & $10 \cdot 5$ \\
\hline FA2 & $1 \cdot 4$ & $2 \cdot 7$ & $3 \cdot 3$ & $2 \cdot 9$ & $4 \cdot 7$ & $5 \cdot 8$ & $4 \cdot 6$ & $7 \cdot 9$ & $10 \cdot 4$ \\
\hline FA3 & $1 \cdot 3$ & $2 \cdot 4$ & $3 \cdot 1$ & $3 \cdot 1$ & $5 \cdot 5$ & $6 \cdot 3$ & - & - & - \\
\hline FA4 & 1.6 & $3 \cdot 0$ & $3 \cdot 5$ & $2 \cdot 7$ & $5 \cdot 1$ & 5.9 & 4.5 & $8 \cdot 2$ & $10 \cdot 6$ \\
\hline FA5 & $1 \cdot 8$ & $2 \cdot 9$ & $3 \cdot 6$ & $2 \cdot 7$ & $4 \cdot 8$ & $5 \cdot 9$ & $4 \cdot 5$ & $7 \cdot 9$ & $10 \cdot 4$ \\
\hline FA6 & $1 \cdot 5$ & $2 \cdot 6$ & $3 \cdot 0$ & $2 \cdot 2$ & $5 \cdot 0$ & $6 \cdot 0$ & - & - & - \\
\hline FA7 & $1 \cdot 3$ & $2 \cdot 4$ & $3 \cdot 0$ & $2 \cdot 8$ & $5 \cdot 5$ & $6 \cdot 7$ & $4 \cdot 7$ & $8 \cdot 0$ & $10 \cdot 5$ \\
\hline FA8 & $1 \cdot 5$ & $2 \cdot 7$ & $3 \cdot 3$ & $2 \cdot 7$ & $5 \cdot 0$ & $6 \cdot 0$ & $5 \cdot 4$ & $8 \cdot 4$ & $10 \cdot 6$ \\
\hline FA9 & 1.4 & $2 \cdot 4$ & 2.9 & 2.9 & $5 \cdot 7$ & $6 \cdot 5$ & - & - & - \\
\hline
\end{tabular}

determined from the difference in total alumina (X-ray fluorescence spectrometry) and alumina bound in mullite (X-ray diffraction) (i.e. reactive alumina present in concrete $\left(\mathrm{kg} / \mathrm{m}^{3}\right)$ ). This indicates that, although there is some scatter in the data, a general reduction occurred in chloride diffusion with increasing reactive alumina content in concrete. The effects of microstructure with the changing w/c ratio (between strengths of 35 and $45 \mathrm{MPa}$ ) are also evident in the data.
The results from the 1990s study (using a different type of chloride test, two-compartment cell, which tends to give lower values for the property) indicate similarities in trends for the two studies. The two distinct groups in the 1990s data in Figure 7 indicate that there may be a maximum reactive alumina content, around $30 \mathrm{~kg} / \mathrm{m}^{3}$, beyond which there is little further reduction in chloride diffusion. This type of behaviour has been noted previously in chloride binding and diffusion 


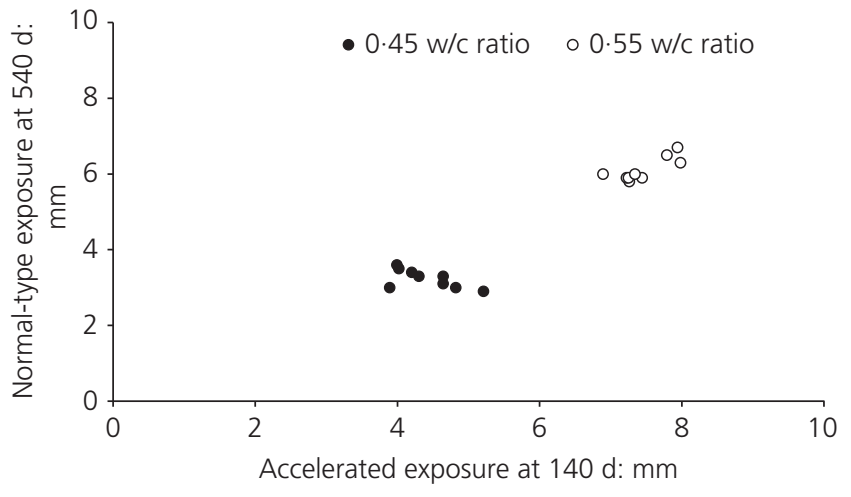

Figure 5. Comparison between accelerated and normal-type carbonation exposure test results for 0.45 and $0.55 \mathrm{w} / \mathrm{c}$ ratio fly ash concretes

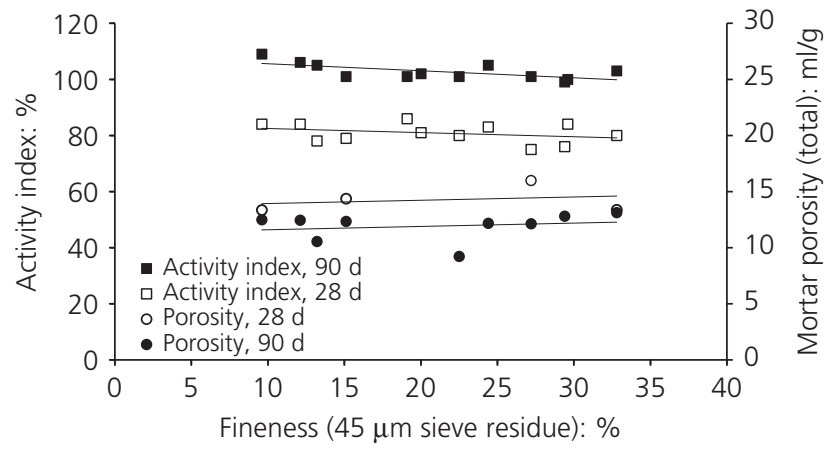

Figure 6. Comparison of fineness, reactivity and porosity for selective fly ash mortars

tests on concrete for fly ash used at various levels in the binder (Dhir et al., 1997).

Similar effects are evident between the chloride diffusion results and glass (glass/others) content of fly ash. In this case, a gradual reduction in chloride diffusion with increasing glass content was noted for the modern fly ash concretes. This is reasonable given the linear relationship between glass content and reactive alumina for fly ash noted in data from Moreno et al. (2005). There is general agreement with the 1990s data (Figure 7), which, like reactive alumina, suggest that there is a maximum effective value for glass content - in this case around $100 \mathrm{~kg} / \mathrm{m}^{3}$.

The comparisons of fineness and chloride diffusion for the modern fly ashes (Figure 8) show gradual increases in chloride diffusion with coarsening of fly ash. Given the basis of comparison is equal strength (which tends to reduce differences in microstructure), the observed effects may correspond to the influences of finer fly ash on surface area for chemisorption and binding of chloride. This, again, gives general agreement with that noted previously in the 1990s for $40 \mathrm{MPa}$ concrete.
Overall, the data suggest both physical and chemical factors influence chloride ingress and that there is similar behaviour between the current and previous studies.

The carbonation depth results following $540 \mathrm{~d}$ normal-type exposure for the modern fly ash concretes (at equal strength) are shown against fineness in Figure 9. This indicates that there are only minor variations in carbonation depth between fly ash concretes with changing fineness. It is evident, as noted above, that similar effects in accelerated tests have been found previously (Dhir et al., 1998), where adjustments in w/c ratio were made to achieve equal strength between different fineness fly ash concretes.

The data from tests on various fly ash concretes carried out in a study from the early 1990s (Thomas and Matthews, 1992) are also shown in Figure 9. In this case, higher strength concretes (although referred to as C25 and C35), with similar curing and exposure conditions (with tests at $730 \mathrm{~d}$ ) but a narrower fly ash fineness range, were used. As with chloride ingress, there were differences in concrete mixes, which could influence carbonation results. However, it is evident that there were only minor variations in depths, and similar effects with respect to fly ash fineness between the current and 1990s study.

Given the short-term curing used for the concretes $(7 \mathrm{~d}$ in water) in Figure 9, it is likely that influences due to pozzolanic reactions, which tend to start later than $7 \mathrm{~d}$ for the conditions used (McCarthy et al., 2017b), would be limited. It is probable that any differences in carbonation between fly ash concretes would then correspond to dispersion of PC flocs and early filler effects on PC hydration/particle packing (Dhir, 1986; Lothenbach et al., 2011; Tangpagasit et al., 2005). The data suggest that either these have a small influence on carbonation, or that variations between fine and coarse fly ash are reduced when comparing at equal strength.

\section{Practical implications}

The study has shown that, while modern coal-fired power technologies may have some effect on fly ash properties, their influence on the aspects of durability being investigated gave general agreement with data obtained from previous research on fly ashes. Although the findings are specific to the materials included in the study, they demonstrate that modern fly ashes follow expected behaviour. This is of increasing importance given the anticipated developments in sourcing material (Carroll, 2014), including greater international trade (McCarthy et al., 2017a) and the range of technologies likely to have an impact on fly ash (Barnes, 2011).

To examine the influence of the physical and chemical properties of fly ash on chloride ingress (material dependent), the ranking of fineness (in terms of sub-10 $\mu \mathrm{m}$ 


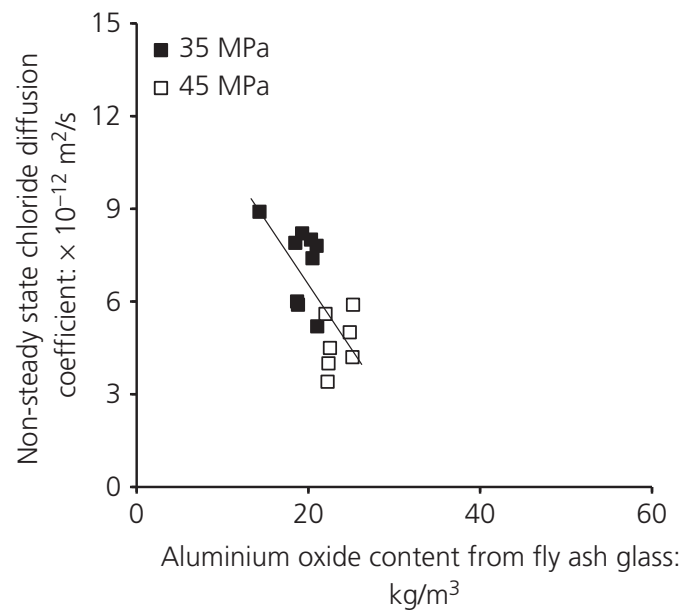

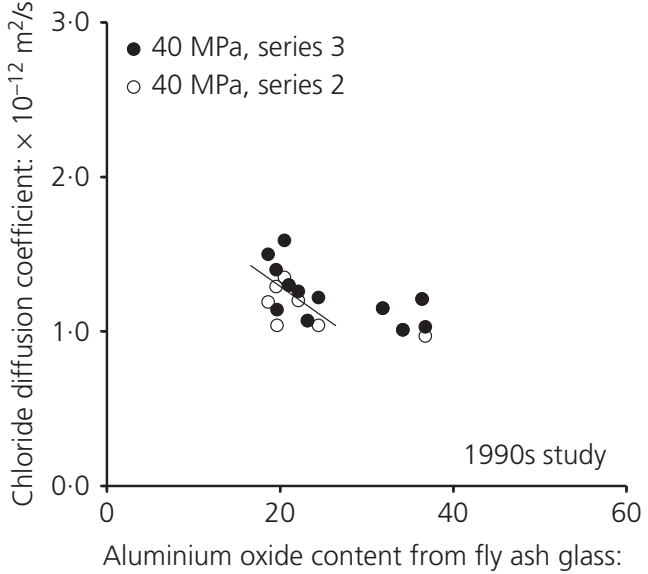

$\mathrm{kg} / \mathrm{m}^{3}$

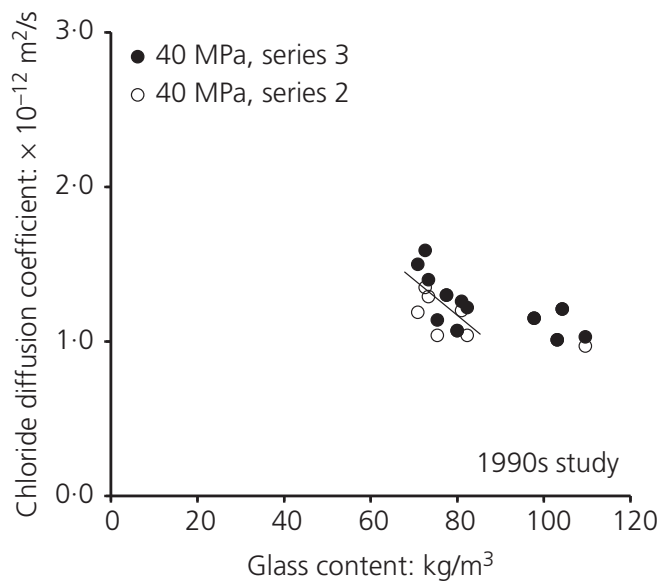

Figure 7. Relationship between reactive alumina (aluminium oxide content from fly ash glass) and glass contents with non-steady state chloride diffusion coefficient (current study, left) and between reactive alumina and chloride diffusion coefficient (1990s study, right)
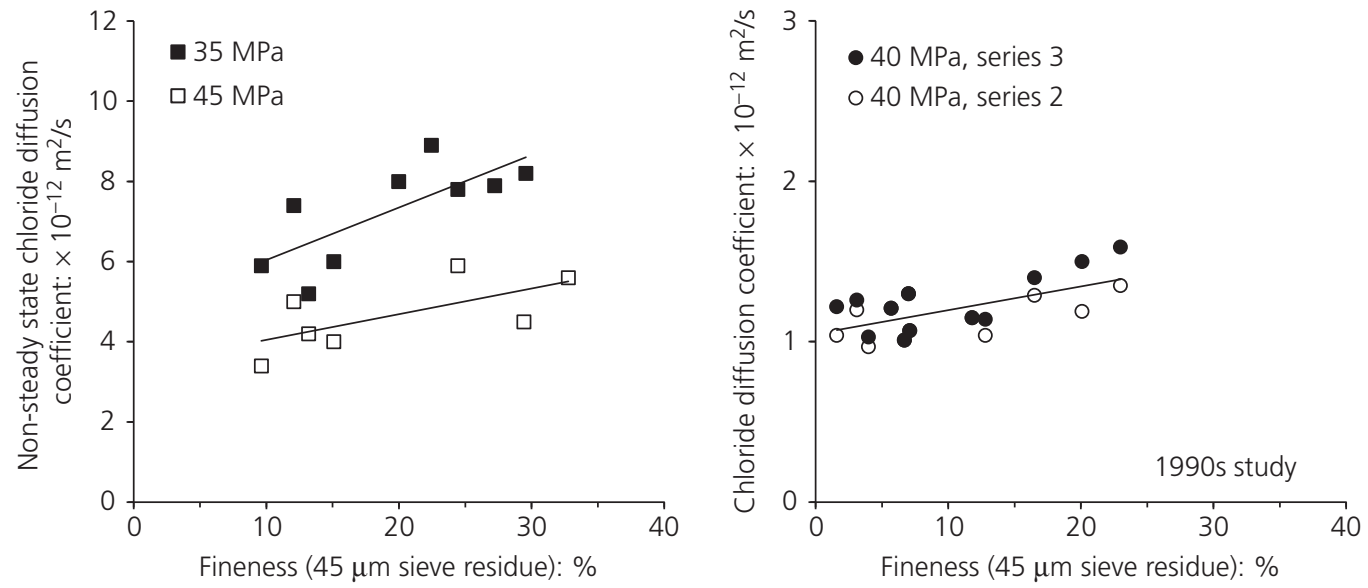

Figure 8. Relationship between fineness ( $45 \mu \mathrm{m}$ sieve residue) and non-steady state chloride diffusion coefficient (current study, left) and chloride diffusion coefficient (1990s study, right) 

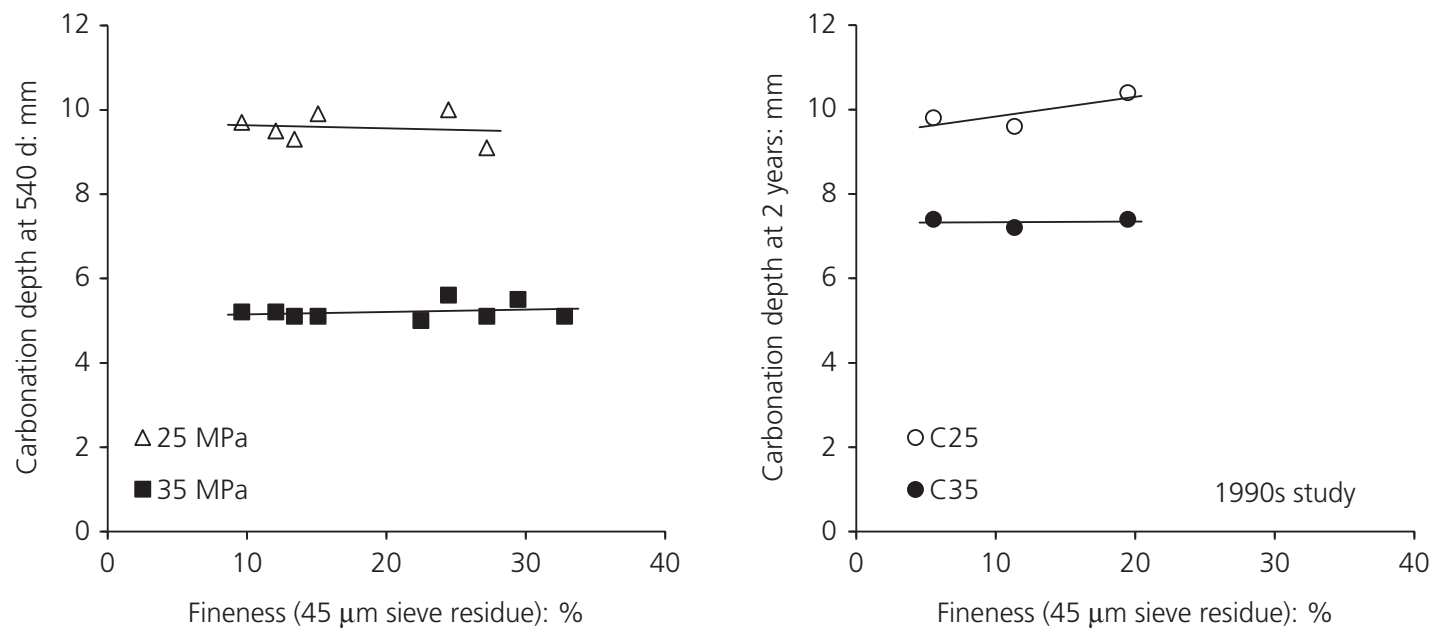

Figure 9. Relationship between fineness ( $45 \mu \mathrm{m}$ sieve residue) and carbonation depth $\left(0.035 \%\right.$ carbon dioxide, $20^{\circ} \mathrm{C}$ temperature and $65 \% \mathrm{RH})$ : current study, left; internal storage: 1990s study, right

Table 6. Comparison of ranking for fly ash fineness (sub-10 $\mu \mathrm{m}$ content), reactive alumina content and chloride diffusion coefficient of concrete $(\mathrm{w} / \mathrm{c}=0.45)$

\begin{tabular}{|c|c|c|c|}
\hline Fly ash & $\begin{array}{l}\text { Sub-10 } \mu \mathrm{m} \\
\text { content: } \\
\text { ranking } \\
(\% \text { vol. })\end{array}$ & $\begin{array}{l}\text { Reactive } \\
\text { alumina } \\
\text { content: } \\
\text { ranking (\%) }\end{array}$ & $\begin{array}{l}\text { Non-steady } \\
\text { state chloride diffusion } \\
\text { coefficient: ranking } \\
\left(\times 10^{-12} \mathrm{~m}^{2} / \mathrm{s}\right)\end{array}$ \\
\hline \multicolumn{4}{|c|}{ Reference } \\
\hline FA1 & $1(44 \cdot 5)$ & $4(12 \cdot 7)$ & $1(3 \cdot 4)$ \\
\hline FA2 & $3(39 \cdot 7)$ & $1(14.4)$ & $3(4 \cdot 2)$ \\
\hline FA3 & $7(26 \cdot 7)$ & $8(12 \cdot 1)$ & $9(6.4)$ \\
\hline \multicolumn{4}{|c|}{$\mathrm{NO}_{x}$ reduction } \\
\hline FA4 & $4(32 \cdot 7)$ & $3(13 \cdot 6)$ & $5(5 \cdot 2)$ \\
\hline FA5 & $2(39.8)$ & $9(11.9)$ & $2(4 \cdot 1)$ \\
\hline FA6 & $5(32 \cdot 2)$ & $11(8 \cdot 9)$ & $12(6 \cdot 9)$ \\
\hline \multicolumn{4}{|c|}{ Co-combustion } \\
\hline FA7 & $6(26 \cdot 9)$ & $2(14 \cdot 1)$ & $7(6 \cdot 3)$ \\
\hline FA8 & $9(23 \cdot 6)$ & $6(12 \cdot 3)$ & $10(6 \cdot 5)$ \\
\hline FA9 & $8(24 \cdot 4)$ & $5(12.5)$ & $4(4 \cdot 7)$ \\
\hline \multicolumn{4}{|c|}{ Supercritical } \\
\hline FA10 & $11(22 \cdot 3)$ & $7(12 \cdot 3)$ & $6(6 \cdot 2)$ \\
\hline FA11 & $10(23 \cdot 2)$ & $10(11 \cdot 6)$ & $8(6 \cdot 3)$ \\
\hline \multicolumn{4}{|l|}{ Oxy-fuel } \\
\hline FA12 & $12(15 \cdot 0)$ & $12(6 \cdot 8)$ & $11(6 \cdot 9)$ \\
\hline
\end{tabular}

content; i.e. the main reactive particles (Gambhir, 2013; Payá et al., 1995)), reactive alumina and chloride diffusion coefficient $(w / c=0.45)$ is given in Table 6. This indicates that the sub-10 $\mu \mathrm{m}$ content mainly ranged from 20 to $45 \%$, while reactive alumina was between 11.5 and $14.5 \%$. In terms of the ranking for chloride ingress in fly ash concrete, these highlight the importance of having high fineness and high reactive alumina content. This is also reflected in the relationship between the product of sub-10 $\mu \mathrm{m}$ and reactive alumina contents, and chloride diffusion, as shown in Figure 10 (with $\left.R^{2}=0 \cdot 70\right)$.

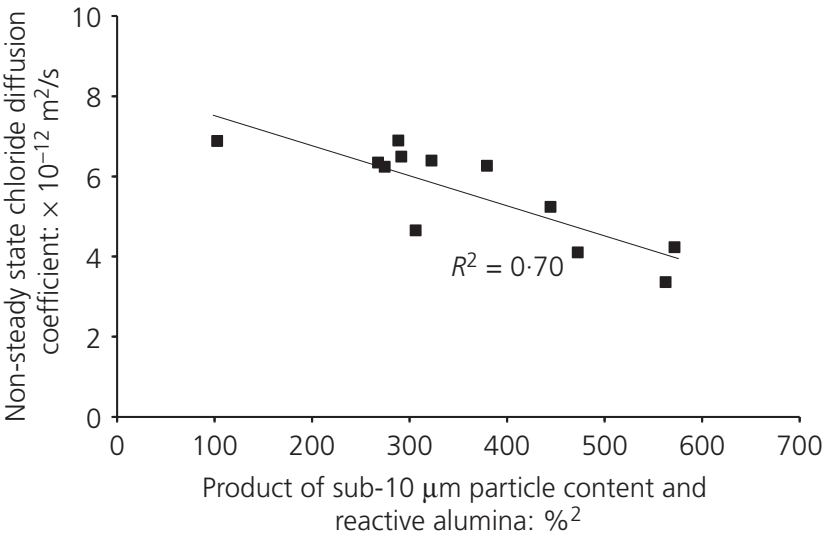

Figure 10. Relationship between the product of sub-10 $\mu \mathrm{m}$ and reactive alumina contents and non-steady state chloride diffusion coefficient of fly ash concretes $(\mathrm{w} / \mathrm{c}=0.45)$

\section{Conclusions}

Preliminary tests on selective fly ashes using the NT Build 492 method indicate that material from modern technologies can have some effect on chloride ingress in concrete. Factors associated with fly ash previously identified as affecting the process, including fineness and alumina content, appeared to have a role. Less difference between fly ash concretes was apparent with reducing w/c ratio.

Tests following the prEN 12390-11 method gave typical chloride profiles for modern fly ash concretes. The chloride diffusion results gave similar effects to those found in the accelerated tests, with fineness and alumina content generally influencing behaviour. Between the different fly ashes, effects tended to be greater at higher w/c ratio, with concrete containing some of the modern fly ashes (in particular in-combustion 
$\mathrm{NO}_{x}$ reduction, co-combustion (wood chip), supercritical steam and oxy-fuel combustion) appearing to be at the upper end of the range.

Both accelerated and normal-type exposure tests were carried out to investigate carbonation between the different modern fly ash concretes. The results for both series gave increasing carbonation depth with time, but at a gradually reducing rate. There appeared to be little influence of modern fly ashes on the process, with similar behaviour occurring for the range of w/c ratios and two carbonation test conditions.

Tests on standard fly ash mortars of equal w/c ratio $(0 \cdot 5)$, with $25 \%$ fly ash in the binder for reactivity (by activity index) and porosity (by MIP), indicate that there were small influences of fineness on these properties for the various modern fly ashes, with similar behaviour generally apparent at the two test ages (28 and $90 \mathrm{~d}$ ) for both. The results gave general agreement for the properties to those noted previously with fly ash.

Comparisons of the results of the current study for both chloride ingress and carbonation with respect to studies carried out during the 1990s indicate similar effects with respect to reactive alumina (content in the glass), glass content and fineness for the former, and fineness for the latter. A relationship was found for the product of reactive alumina and sub- $10 \mu \mathrm{m}$ contents of the fly ashes and chloride ingress in concrete.

Overall, it appears that, while the modern coal-fired power technologies may have some effect on fly ash characteristics, the materials have similar influences on the concrete durability properties investigated to those noted previously.

\section{Acknowledgements}

Acknowledgement is given to the Engineering and Physical Science Research Council (Doctoral Training Award) and the UK Quality Ash Association and its members for funding the research described. Thanks are also given to Dr Robert Carroll and Dr Lindon Sear for their helpful technical input. Miss M. Kokkini's contribution to the experimental work is also appreciated.

\section{REFERENCES}

Angst U, Elsener B, Larsena CK and Vennesland Ø (2009) Critical chloride content in reinforced concrete - a review. Cement and Concrete Research 39(12): 1122-1138.

Atis CD (2003) Accelerated carbonation and testing of concrete made with fly ash. Construction and Building Materials 17(3): 147-152.

Barnes I (2010) Ash Utilisation - Impact of Recent Changes in Power Generation Practices. IEA Clean Coal Centre, London, UK. CCC/176, Report IEACR/50.

Baroghel-Bouny V, Nguyen TQ and Dangla P (2009) Assessment and prediction of RC structure service life by means of durability indicators and physical/chemical models. Cement and Concrete Composites 31(8): 522-534.
Beer JM (2007) High efficiency electric power generation: the environmental role. Progress in Energy and Combustion Science 33(2): 107-134.

BEIS (Department for Business, Energy and Industrial Strategy) (2017) UK Energy in Brief 2017. BEIS, London, UK. See https://www. gov.uk/government/statistics/uk-energy-in-brief-2017 (accessed 13/11/2018).

Bijen J (1996) Benefits of fly ash and slag. Construction and Building Materials 10(5): 309-314.

BSI (2002) BS EN 12620: Aggregates for concrete. BSI, London, UK.

BSI (2007) BS EN 14629: Products and systems for the protection and repair of concrete structures. Test methods. Determination of chloride content in hardened concrete. BSI, London, UK.

BSI (2009) BS EN 934-2: Admixtures for concrete, mortar and grout. Part 2: concrete admixtures - definitions, requirements, conformity, marking and labelling. BSI, London, UK.

BSI (2011) BS EN 197-1: Cement. Part 1: composition, specifications and conformity criteria for common cements. BSI, London, UK.

BSI (2012) BS EN 450-1: Fly ash for concrete. Definition, specifications and conformity criteria. BSI, London, UK.

BSI (2013a) BS 1881-125: Testing concrete. Methods for mixing and sampling fresh concrete in the laboratory. BSI, London, UK.

BSI (2013b) BS 1881-210: Testing hardened concrete. Determination of the potential carbonation resistance of concrete. Accelerated carbonation method. BSI, London, UK.

BSI (2015) BS 8500-1: Concrete - complementary British standard to BS EN 206. Part 1: method of specifying and guidance for the specifier. BSI, London, UK.

BSI (2016) BS EN 196-1: Methods of testing cement. Determination of strength. BSI, London, UK.

Buhre BJP, Elliott LK, Sheng CD, Gupta RP and Wall TF (2005) Oxy-fuel combustion technology for coal-fired power generation. Progress in Energy and Combustion Science 31(4): 283-307.

Carroll RA (2014) Fly ash for concrete and the potential for stockpile ash. In Euro CoalAsh 2014, International Conference, Munich, Germany. VGB Power-Tech, Essen, Germany, pp. 209-220.

CEN (Comité Européen de Normalisation) (2007) prEN 12390-10: Testing hardened concrete - part 10: determination of the carbonation resistance of concrete at atmospheric levels of carbon dioxide. CEN, Brussels, Belgium.

CEN (2013) prEN 12390-11: Testing hardened concrete. Determination of the chloride resistance of concrete, unidirectional diffusion. CEN, Brussels, Belgium.

Chindaprasirt P, Jaturapitakkul C and Sinsiri T (2005) Effect of fly ash fineness on compressive strength and pore size of blended cement paste. Cement and Concrete Composites 27(4): 425-428.

Chindaprasirt P, Chotithanorm C, Cao HT and Sirivivatnanon V (2007) Influence of fly ash fineness on the chloride penetration of concrete. Construction and Building Materials 21(2): 356-361.

CS (Concrete Society) (2011) Cementitious Materials: the Effect of GGBS, Fly Ash, Silica Fume and Limestone Fines on the Properties of Concrete. The Concrete Society, Camberley, Surrey, UK, Technical Report 74.

Dhir RK (1986) Pulverised fuel ash. In Cement Replacement Materials (Swamy RN (ed.)). Surrey University Press, Guildford, Surrey, UK, pp. 197-255.

Dhir RK, Jones MR and Seneriratne AMG (1991) Diffusion of chlorides into concrete influence of PFA quality. Cement and Concrete Research 21(6): 1092-1102.

Dhir RK, Dyer TD and El-Mohr MAK (1997) Developing chloride resisting concrete using PFA. Cement and Concrete Research 27(11): 1633-1639.

Dhir RK, McCarthy MJ and Magee BJ (1998) Impact of BS EN 450 PFA on concrete construction in the UK. Construction and Building Materials 12(1): 59-74. 
Dhir RK, McCarthy MJ, Csetenyi LJ and Brindle JH (2005) Co-Combustion in Electricity Generation, and the Properties of Fly Ash for Use in Concrete Construction. DTI Research Contract No 39/3/678 CC2255. University of Dundee, Dundee, UK

Dyer TD (2014) Concrete Durability. CRC Press, Boca Raton, FL, USA.

Faustino P, Chastre C, Nunes Â and Brás A (2016) Lifetime modelling of chloride-induced corrosion in concrete structures with Portland and blended cements. Structure and Infrastructure Engineering 12(9): 1013-1023.

Franco A and Diaz AR (2009) The future challenges for 'clean coal technologies': joining efficiency increase and pollutant emission control. Energy 34(3): 348-354.

Frias M, Goñi S, García R and Vigil de La Villa R (2013) Seawater effect on durability of ternary cements. Synergy of chloride and sulphate ions. Composites: Part B 46(3): 173-178.

Gambhir SK (2013) Concrete Technology: Theory and Practice, 5th edn. TataMcGraw Hill, New Delhi, India.

Jones MR, Dhir RK, Newlands MD and Abbas AMO (2000) A study of the CEN test method for measurement of the carbonation depth of hardened concrete. Materials and Structures 33(226): $135-142$.

Kandasami S, Harrison TA, Jones MR and Khanna G (2012) Benchmarking UK concretes using an accelerated carbonation test. Magazine of Concrete Research 64(8): 697-706.

Loser R, Lothenbach B, Leemann A and Tuchschmid M (2010) Chloride resistance of concrete and its binding capacity - comparison between experimental results and thermodynamic modelling. Cement and Concrete Composites 32(1): 34-42.

Lothenbach B, Scrivener K and Hooton RD (2011) Supplementary cementitious materials. Cement and Concrete Research 41(12): 1244-1256.

Liu J, Ou G, Qui Q et al. (2017) Chloride transport and microstructure of concrete with/without fly ash under atmospheric chloride condition. Construction and Building Materials 146(15): 493-501.

Marques PF, Chastre $C$ and Nunes Â (2013) Carbonation service life modelling of RC structures for concrete with Portland and blended cements. Cement and Concrete Composites 37(3): 171-184.

McCarthy MJ, Robl TL and Csetenyi LJ (2017a) Recovery, processing, and usage of wet stored fly ash. In Coal Combustion Products (CCP's) - Characteristics, Utilization and Beneficiation (Robl T, Oberlink A and Jones R (eds)). Elsevier, Oxford, UK, pp. 343-368.
McCarthy MJ, Yakub HI, Strompinis N and Csetenyi LJ (2017b) Evaluation of fly ash reactivity potential using a lime consumption test. Magazine of Concrete Research 69(18): 954-965.

McCarthy MJ, Yakub HI and Csetenyi LJ (2018) Influence of modern coal-fired power technologies on fly ash properties and its use in concrete. Advances in Cement Research, https://doi.org/10.1680/ jadcr.17.00208.

Moreno N, Querol X, Andrés JM et al. (2005) Physico-chemical characteristics of European pulverized coal combustion fly ashes. Fuel 84(11): 1351-1363.

Nordtest (1999) NT Build 492: Concrete, mortar and cement-based repair materials chloride migration coefficient from non-steady migration experiments. Nordtest, Taastrup, Denmark.

Papadakis VG (1999) Effect of fly ash on Portland cement systems Part I. Low-calcium fly ash. Cement and Concrete Research 29(11): 1727-1736.

Papadakis VG (2000) Effect of supplementary cementing materials on concrete resistance against carbonation and chloride ingress. Cement and Concrete Research 30(2): 291-299.

Payá J, Monzo J, Pera-Mora E et al. (1995) Early strength development of Portland cement mortars containing air classified fly ashes. Cement and Concrete Research 25(2): 449-456.

Scott AN and Thomas MDA (2007) Evaluation of fly ash from co-combustion of coal and petroleum coke for use in concrete. ACI Materials Journal 104(1): 62-69.

Sear LKA (2001) The Properties and Use of Coal Fly Ash: A Valuable Industrial Byproduct. Thomas Telford, London, UK.

Tangpagasit J, Cheerarot R, Jaturapitakkul C and Kiattikomol K (2005) Packing effect and pozzolanic reaction of fly ash in mortar. Cement and Concrete Research 35(6): 1145-1151.

Teychenné DC, Franklin RE and Erntroy HC (1997) Design of Normal Concrete Mixes, 2nd edn. BRE Press, Watford, UK.

Thomas MDA (2007) Optimising the Use of Fly Ash in Concrete. Portland Cement Association, Skokie, IL, USA.

Thomas MDA and Matthews JD (1992) Carbonation of fly ash concrete. Magazine of Concrete Research 44(160): 217-228.

Thomas MDA, Hooton RD, Scott A and Zibara H (2012) The effect of supplementary cementitious materials on chloride binding in hardened cement paste. Cement and Concrete Research 42(1): 1-7.

Yuan Q, Shi C, De Schutter G, Audenaert K and Deng D (2009) Chloride binding of cement-based materials subjected to external chloride environment - a review. Construction and Building Materials 23(1): $1-13$.

\section{How can you contribute?}

To discuss this paper, please submit up to 500 words to the editor at journals@ice.org.uk. Your contribution will be forwarded to the author(s) for a reply and, if considered appropriate by the editorial board, it will be published as a discussion in a future issue of the journal. 